\title{
誘導型無電極ランプの電子密度解析
}

$\begin{array}{lllll}\text { 正会員 } & \text { 掛橋 } & \text { 英典（パナソニック電工株式会社） 正会員 佐藤 } & \text { 歩（パナソニック電工株式会社） } \\ \text { 非会員 柳井 武志 (長崎大学) } & \text { 正会員 福永 博俊 (長崎大学) 専門会員 植月 唯夫 (津山工高等専門学校) }\end{array}$

\section{Analyzing Electron Density in an Induction-coil-type Electrodeless Lamp}

Member Hidenor i Kakehashi(Panasonic Electric Works Ltd.),

Member Ayumu Sato(Panasonic Electric Works Ltd.), Non-Member Takeshi Yanai(Nagasaki University),

Member Hi rotoshi Fukunaga(Nagasaki University) and Fellow Member Tadao Uetsuki(Tsuyama National College of Technology)

\begin{abstract}
Using a $135-\mathrm{kHz}$ induction-coil-type electrodeless lamp system offers several advantages including high efficiency, long life, and low resource consumption. To optimize the lamp dimensions, electron density was analyzed by the complex finite element method for magnetic fields and plasma. Magnetic flux density, current density, and electric field distribution were derived from magnetic analysis. The electron temperature and ionizing frequency were then calculated on the basis of the electric field. The distributions of electron density were subsequently deduced by solving diffusion equations. The maximum value of electron density for a 150 -W bulbous electrodeless lamp was $1.5 \times 10^{18} \mathrm{~m}^{-3}$ near the induction coil. The analyzed distributions are in agreement with the experimental ones.
\end{abstract}

KEYWORD : electrodeless lamp, electron density, finite element method

\section{1.はじめに}

無電極ランプは電極を持たないため, 本質的に長寿命でランプ交 換が不要であること, 電子放射物質の飛散がなく蛍光体やガラスの リサイクルが容易であるといった優れた特長を有している． 2004 年にはじめて実用化されたスイッチング帯域の周波数 $135 \mathrm{kHz}$ を利 用した誘導型無電極ランプシステム 1)-3)は高いシステム効率を有し 装飾や屋外照明のみならず屋内照明分野へも広く展開されている. 省エネ, 省資源, 資源再利用といった観点から地球環境にやさしい 次期光源としての可能性を秘めており, 今後さらなる発光効率の向 上が求められている. 誘導型無電極ランプの発光プロセスは電気エ ネルギーを磁気結合によってプラズマに伝達し励起水銀の紫外線 放射を経て蛍光体で可視光に変換されるものである. それぞれの過 程で性能向上を追求していくために, プラズマの基本量として電子 温度や電子密度の把握は重要である. 対象とする無電極ランプは開 磁路コアをもつ誘導コイルを内包した球状バルブ構造で, 空間に広 く磁束が存在しその誘導電界で形成されるプラズマも分布をもつ たものとなる. 電子温度や電子密度の計測は煩雑であり, また多く の測定点を得ることは困難であることから数值解析の適用を試み た. 数值解析の過去の研究としては渡辺らが無電極ランプの等価回 路を用いて放電特性の解明を報告した例 4)がありこれによると, ラ ンプを無限管長, 管壁の電子はゼロと仮定して電子の拡散方程式を 解き, 電子密度分布は測定した励起水銀原子密度の分布と良好な一 致を示すことを明らかにしている.しかしこの報告ではバルブを無
限長と仮定しているため実際のランプへの適用が困難であった. そこで本論文では有限長をもつランプのプラズマの状態を明ら かにするために, 有限要素法 (Finite Element Method) を用いて, 磁 気とプラズマの連成解析を実施する. 球状無電極ランプの安定点 灯状態における電子密度とその分布について知見を得ることを 目的とする. まず, $135 \mathrm{kHz}$ 誘導型無電極ランプシステムの概要 について述べ, 解析対象である球状ランプの諸元と解析のための モデリング方法について説明する. 次に, 全体の解析手順を示し てフローに従って, 磁場方程式による磁束密度・電界分布の導出 方法, 電子温度と電離周波数を決定する式, および拡散方程式を 用いた電子密度の解析方法を述べる. 境界条件や収束条件などを 明らかにして解析を実施し最終的に得られた電子密度分布を示 す.さらに, ダブルプローブ法による定点における実測值とも対 比を行う.

\section{2. 解析モデル}

解析対象は $150 \mathrm{~W}$ 出力の $135 \mathrm{kHz}$ 誘導型無電極ランプシステム 1)で図 1 にこのシステムの外観を示す. ランプとインバータ点灯 装置から構成され，ランプは図 2 に示した断面のように内壁面に 蛍光体が塗布された球状バルブと誘導コイルからなっている. バ ルブの中央にはキャビティと呼ばれる空間が設けられており誘 導コイルはキャビティに内接するように配置される. キャビティ の中心にはバルブ形成過程で内部ガスを置換するためのガラス製 


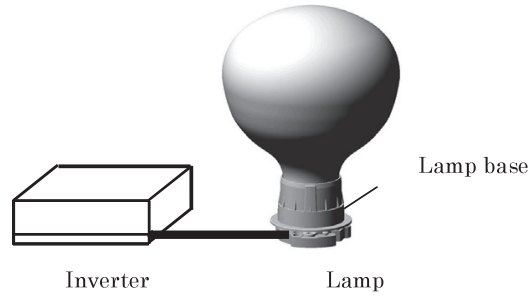

図 1 誘導型無電極ランプシステム

Fig.1 Induction-coil-type electrodeless lamp system.

細管がバルブ空間から下方へ突出している. 誘導コイルはバルブか らの熱を排出するための金属放熱体，放熱体に装着された円筒状フ エライトコアおよびコアの外周の巻線からなり, コアの軸方向と巻 線軸方向は一致するため開磁路のコイル構成である. インバー夕か らの $135 \mathrm{kHz}$ の高周波出力で誘導コイルが励磁され, 誘導磁気結合 によってバルブ中のプラズマにうず電流が形成されて電力が供給 される. 開磁路コアの構成であることから磁束はバルブ内外の空間 に広く分布し理論解析は困難であるため有限要素法を適用して進 めることとした. ランプの形状は球状であるため円筒座標系 $(r, \theta, z)$ を用いて誘導コイルの軸を $z$ 軸とし, $r z$ 平面における軸対称三次元 モデルとして取り扱った. 図 3 に各部のディメンジョンを示して おり, コイル電流は巻線部分において一様な電流密度をもった定電 流源とみなし原点の $z$ 座標はフェライトコアと電流源の中央とし た. また, 軸対称三次元では $z$ 軸に対して左右刘称であるため右側 $1 / 2$ モデルについて解析を行った.

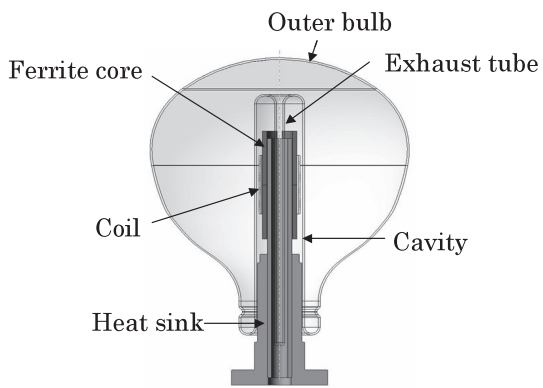

図 2 ランプ構造

Fig.2 Structure of the lamp.

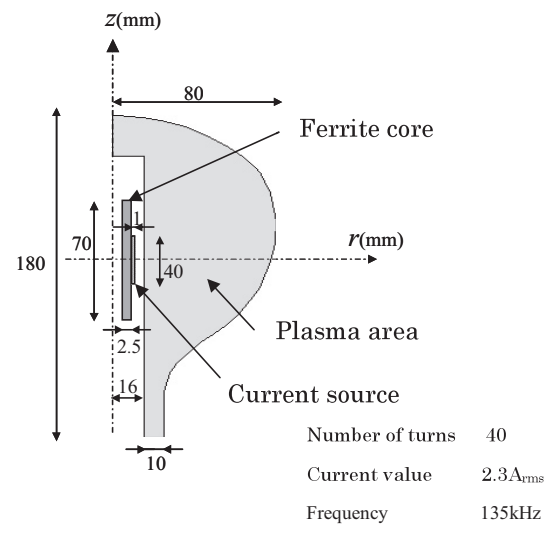

図 3 軸対称三次元によるランプのモデリング

Fig.3 Modeling of the lamp.

\section{3. 解析方法}

\section{1 解析手順}

電子密度を求める力法に関し，まずバルブ内空間に電子がある 一定量一様に存在すると考える. 誘導コイルへの通電により磁界 とその誘導電界によるうず電流でプラズマの状態が変化して電 子密度の分布が変わる. すると再び誘導電界が変化して電子密度 分布がさらに変化する.このように解析結果が再び入力条件とな つて逐次変化していくものの最終的にはある電子密度の值, 分布 に収束するであろうと想定した．解析の手順を図４に示してお り, プラズマの種となる初期電子密度を仮定して導電率を求めコ イル電流を与えることで解析は開始される. コイルが作る磁界と 磁界の時間変化に伴ううず電流が導かれてプラズマ空間の磁束 密度, 電流密度および電界が算出される, 次に, 電子温度は電界 から近似式で導出され, 電子温度から電離周波数が決定されるこ とにより電子密度が算出される. さらに, 得られた電子密度を用 いてプラズマの導電率が再計算され再び磁束密度が求められる. 同様の流れに沿って, 磁束密度から電子密度を算出するまでのル 一プを収束するまで繰り返される. 図40点線部に示すように解 析は大別して, 磁場支配方程式を解いて磁束密度から電界を得る までの流れと電子温度, 電離周波数からプラズマの拡散方程式を 解いて電子密度分布を得るまでのふたつのプロセスがありそれ ぞれ, 磁場解析, プラズマ解析と呼んで以下に詳述する. なお有 限要素法による解析部分には汎用プログラム「ANSYS ${ }^{\circledR} 」$ 応用し た.

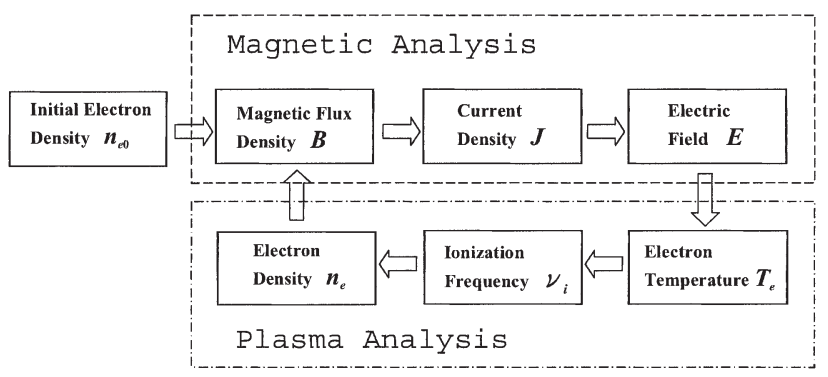

\section{図 4 解析手順}

Fig.4 Flow of the proposed method.

\section{2 磁場解析}

有限要素法を用いて磁場の支配方程式を解くことにより, 各要 素の磁束密度, 電流密度および電界が解析的に求められる. 磁束 密度を $B$ として磁気ベクトルポテンシャル $A$ を,

$\boldsymbol{B}=\operatorname{rot} \boldsymbol{A}$

で定義する. $\nu$ を磁気抵抗率(透磁率の逆数), $J_{0}$ を強制電流密度, $\sigma$ を導電率, $\phi$ はスカラポテンシャルとすると支配方程式は,

$\operatorname{rot}(\nu \operatorname{rot} \boldsymbol{A})=\boldsymbol{J}_{0}-\sigma \frac{\partial \boldsymbol{A}}{\partial t}-\sigma \operatorname{grad} \phi$

で表される5). 軸刘称三次元モデルでは磁気ベクトルポテンシャ ルおよびコイル部の強制電流は $\theta$ 方向成分のみなのでこれらを $A_{\theta}, J_{0 \theta}$ とおきかつフェライトは異方性をもたないので対象とする 空間領域では磁気抵抗率が一定值 $\nu の$ 等方材料のみとすると $(2)$ 式は円筒座標系 $(r, \theta, z)$ を用いて, 
$\frac{\partial}{\partial r}\left[v \frac{1}{r}\left\{\frac{\partial}{\partial r}\left(r A_{\theta}\right)\right\}\right]+\frac{\partial}{\partial z}\left(v \frac{\partial A_{\theta}}{\partial z}\right)$

$$
=-J_{0 \theta}+\sigma \frac{\partial A_{\theta}}{\partial t}+\sigma\left(\frac{1}{r}\right) \frac{\partial \phi}{\partial \theta}
$$

と表すことができる.

ところで, 一般にプラズマ内の電流密度 $J_{p}$ は電子およびイオンの 密度 $n_{e}, n_{i}$ と移動度 $\mu_{e}, \mu_{i}$ を用いると電気素量を $e$ として次式で与 えられる。

$J_{p}=-e n_{e} \mu_{e} E+e n_{i} \mu_{i} E$

電気的中性から $n_{e} \cong n_{i}$ であり $\mu_{e} » \mu_{i}$ であるので, プラズマ電流の 大部分は電子が担うと仮定してプラズマの導電率 $\sigma_{p}$ は, 次式で表 した.

$\sigma_{p}=e n_{e} \mu_{e}$

初期電子密度は $n_{e}=n_{e 0}$ として, 繰り返し解析においては直前の解 析の結果である電子密度の值を(5)式に入力して導電率 $\sigma_{p}$ を求め た. 電子移動度 $\mu_{e}$ は, 電界 $E$ とガス圧 $p$ の比 $E / p$ が 100[V/cm·Torr $]$ よりも小さい場合電界の強さや向きに依存しないというランジェ バンの計算結果 ${ }^{6}$ に依った. すなわち, $\mathrm{Ar}$ ガス中の電子移動度と压 力 $p$ の積の実験值が $\mu_{e} p=3.3 \times 10\left[\mathrm{~m}^{2} \cdot \mathrm{Torr} / \mathrm{V} \cdot \mathrm{S}\right]$ 与゙えられている7) ので点灯時の $\mathrm{Ar}$ ガスの圧力值から $\mu_{e}=1.88 \times 10^{2}\left[\mathrm{~m}^{2} / \mathrm{V} \cdot \mathrm{S}\right]$ の值とし た.

(3)式を磁気ベクトルポテンシャル $A$ について解くと(1)式から磁 束密度 $B$ が導出され, 電界 $E$ については解析によって得られたプ ラズマ中の電流密度 $J_{p}$ より次式で求めた.

$E(r, z, t)=J_{p}(r, z, t) / \sigma_{p}(r, z)$

一方, コイルへの入力は交流電流であるため磁界および電界も時 間変化し入力電流を,

$i(t)=I_{0} \cos \omega t$

と定義すると, 電界 $E$ は次式で表される.

$E(r, z, t)=E_{0}(r, z) \sin \{\omega t+\varphi(r, z)\}$

ここで, $E_{0}$ は電界 $E$ の振幅, $\varphi$ は入力電流との位相差である. $\omega t=0$ および $\omega t=\pi / 2$ における電界の瞬時值を $E(r, z, t) \omega t=0$, $E(r, z, t) \omega t=\pi / 2$ とすると,

$E(r, z, t)_{\omega t=0}=E_{0}(r, z) \sin \{\varphi(r, z)\}$

$E(r, z, t)_{\omega t=\pi / 2}=E_{0}(r, z) \cos \{\varphi(r, z)\}$

有限要素法による解析結果である電界の瞬時值を用いて(9),(10)式 を連立させて解くことにより振幅 $E_{0}$ と位相差 $\varphi$ の值を算出するこ とができる.

ところで, (8)式のように電界 $E$ は $135 \mathrm{kHz}$ で時間変化しそれによ ってバルブ中の電子密度は何らかの時間的影響を受けると考えら れる. しかし, 一般蛍光ランプにおいて光出力は $20 \mathrm{kHz}$ 以上で高周 波電界には追随できないことが知られており, また実際の照明設計 においても光出力の瞬時值よりも平均值が重要である. そこで今 回, 電子の拡散速度は電界の変化に比べて十分遅いと仮定し次項の プラズマの解析には電界 $E$ の平均值を用いることとした. 算出され た振幅 $E_{0}$ を用いて電界の半周期平均値 $\bar{E}$ は次式で表される.

$\bar{E}=2 E_{0} / \pi$

\section{3 プラズマ解析}

プラズマ中において電子と中性子の衝突で電離が起こり管壁 で再結合する両極性拡散を想定する， $D_{a}$ を両極性拡散係数, $v_{i}$ を電離周波数, $n_{e}$ を電子密度とすると拡散方程式は,

$D_{a} \nabla^{2} n_{e}+v_{i} n_{e}=0$

と表される。 円筒座標系 $(r, \theta, z)$ を用いると(12)式は,

$\frac{D_{a}}{r} \frac{\partial}{\partial r}\left(r \frac{\partial n_{e}}{\partial r}\right)+D_{a} \frac{\partial^{2} n_{e}}{\partial z^{2}}+v_{i} n_{e}=0$

で表され，軸対称三次元モデルで有限要素法を適用した。

両極性拡散係数 $D_{a}$ は, 弱電離プラズマにおいては電子移動度 $\mu_{e}$ 電子温度 $T_{e}$ が, イオン移動度 $\mu_{i}$ ・ イオン温度 $T_{i}$ よりも支配 的な影響を与えると考え, $k$ をボルツマン定数として次式で近似 した.

$D_{a} \cong \frac{k T_{e}}{e} \mu_{i}$

また, 電離の主体は $\mathrm{Hg}$ ガスであると考えその電離周波数 $v_{i}$ に関 しては電子の熱運動によるエネルギ一強度から算出した. 電離電 压 $V_{I}$ 以上のエネルギーにおいて $v_{i}$ は直線的に増加すると仮定し 文献 7から次の近似式に依った。

$v_{i}=N v C_{i}\left(e V+2 k T_{e}\right) \exp \left(-\frac{e V_{I}}{k T_{e}}\right)$

ここで, $N, C_{i}$ はそれぞれ $\mathrm{Hg}$ ガスの密度㧍よび物理定数である. また $m_{e}$ を電子質量として平均電子熱速度 $\bar{v}$ は,

$\bar{v}=\sqrt{\frac{8 k T_{e}}{\pi m_{e}}}$

と表される. $\mathrm{Hg}$ ガスの密度 $N$ は理想気体の状態方程式から次式 に依っている.

$N=\frac{n R_{A}}{V}=\frac{P R_{A}}{R T}$

ここで $n$ は $\mathrm{Hg}$ の $\mathrm{mol}$ 数, $R_{A}$ はアボガドロ定数, $V\left[\mathrm{~m}^{3}\right]$ はバルブ の体積, $P[\mathrm{~Pa}]$ は点灯後定常状態時の $\mathrm{Hg} 0$ 圧力, $R$ は気体定数, $T[\mathrm{~K}]$ は点灯時の $\mathrm{Hg}$ ガスの温度である. (17)式より, 点灯中の $\mathrm{Hg}$ ガスの密度 $N$ として $1.81 \times 10^{20}\left[\mathrm{~m}^{-3}\right]$ の值を得た.

(15)式の中で電子温度 $T_{e}$ については半径 $R[\mathrm{~cm}]$ の陽光柱のモデル を想定し文献 8)より次式で導出した.

$\frac{\exp \left(e V_{I} / k T_{e}\right)}{\sqrt{e V_{I} / k T_{e}}}=1.16 \times 10^{7}(c p R)^{2}$

但し $c\left[\mathrm{Torr}^{-1} \cdot \mathrm{cm}^{-1}\right]$ はガスの種類によって異なる気体定数, $p$ [Torr] は $\mathrm{Ar}$ ガスの圧力である. (18)式より $c p R$ が解机ば電子温度 $T_{e}$ を求めることができるが, $p R$ は Ar ガスにおける電界との関係を 示す実験值から導出した. 図 5 は文献 9 )に示されている電界と压

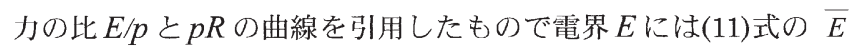
の值を与えることにより $p R$ を求めることができ, これを(18)式 に代人することによって図6のように $T_{e} / V_{I}$ の值が得られた. 最 終的に電界から電子温度 $T_{e}$ を導出することができその結果を図 7 に示す. さらに(15)式で電子温度 $T_{e}$ を変数とした電離周波数 $\mathrm{v}_{i}$ の特性を図 8 に示す. すなわち, 電界から電子温度 $T_{e}$ と電離周 波数 $v_{i}$ が求められることにより拡散方程式である(13)式の各定数 を明らかにした。 


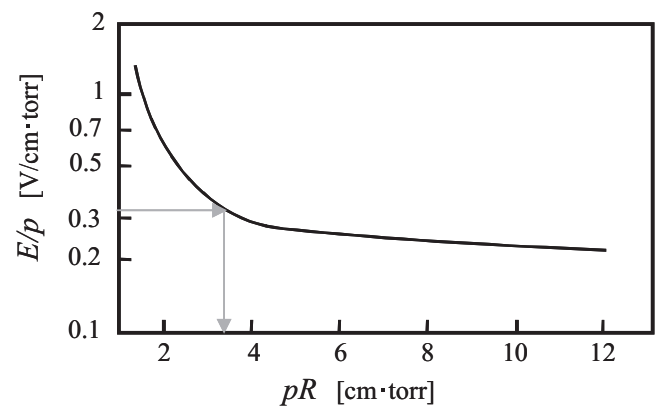

図 5 陽光柱の $E / p$ と $p R$ の実験値

Fig.5 Experimental value of $E / p$ with $p R$.

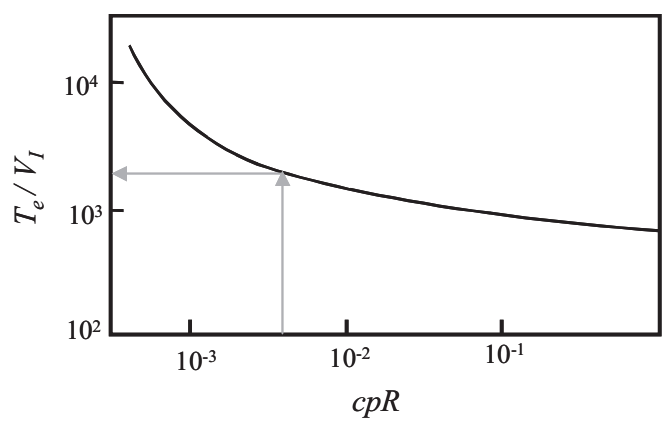

図 6 計算によって求めた $c p R$ と $T_{e} / V_{I}$ の関係曲線 Fig.6 Calculated value of $T_{e} / V_{I}$ with $c p R$.

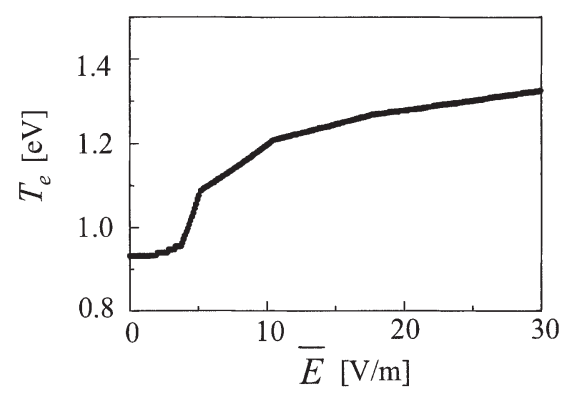

図 7 電界 $\bar{E}$ と電子温度 $T_{e}$ の関係

Fig.7 Characteristics of electron temperature $T_{e}$ with electric field $\bar{E}$

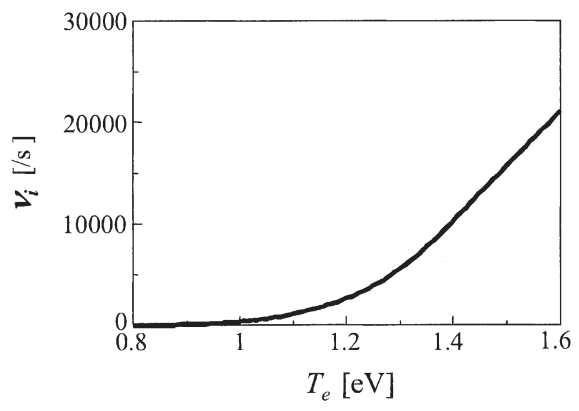

図 8 電子温度 $T_{e}$ と電離周波数 $v_{i}$ の関係曲線

Fig. 8 Characteristics of ionization frequency with electron temperature $\boldsymbol{T}_{e}$.
ところで，有限要素法を用いて複合連成問題を解く場合単一の プログラムで完結するほうが速度や利便性の観点から望ましい と考えられ，拡散方程式(13)を解くにあたって熱伝導方程式との 類似性に着目して汎用プログラム「ANSYS」の伝熱解析を利用し た. 円筒座標系 $(r, \theta, z)$ における定常熱伝導問題の支配方程式は, $\kappa$ を熱伝導率, $T$ を温度, $Q$ を発熱量として,

$\frac{\kappa}{r} \frac{\partial}{\partial r}\left(r \frac{\partial T}{\partial r}\right)+\kappa \frac{\partial^{2} T}{\partial z^{2}}+Q=0$

と表される. (19)式を(13)式と比較すると, 熱伝導率 $\kappa$ を両極性 拡散係数 $D_{a}$ に, 発熱量 $Q$ を $v_{i} n_{e}$ に対応させて方程式を解くこと により温度 $T$ の分布, すなわち電子密度 $n_{e}$ の分布を算出するこ とができる. しかし， $Q$ に対応する $v_{i} n_{e}$ は $v_{i}$ が電界の関数，つ まりは電子密度 $n_{e}$ の関数であるために解を一意に決定すること ができない，そこで解決のためにループ解析を用いて収束させる ことで対処している.すなわち $j$ 回目の解析においては $j-1$ 回目 の解析で得られた $v_{i(j-1)}$ と $n_{e(j-1)}$ の積として(13)式左辺の第 3 項を 与えて解を求め, 電子密度 $n_{e}$ が収束するまで解析を繰り返してい る.

\section{4. 解析および検証}

\section{1 メッシュ分割}

磁場解析において本問題は無限遠方に広がる開領域として解 くべきであるが, 有限要素法では有限の領域を要素分割する手法 であるため適切な範囲の領域を限定して計算を行う必要がある. そこで, 図 9 のようにフェライトコア，コイル部とバルブ内部を 示すプラズマ部，プラズマ外部空間を表す真空部を定め, 真空部 のさらに外側に無限境界要素を定義して境界を設けた。また， $z$ 軸上に軸対称条件を指定した。 無限遠境界にスカラポテンシャル $\phi=0$ の拘束条件を定めて, 全空間領域で磁場解析を行った。 ま た，プラズマ解析ではバルブ管壁でプラズマが消失するとして電 子密度をゼロと定義しプラズマ部のタの領域を対象として解析 を進めた．定義した各領域の材料特性を表 1 に示す。

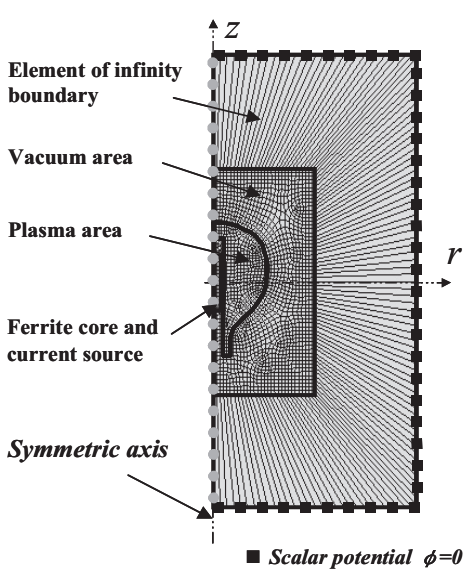

図 9 メッシュ分割図

Fig.9 Mesh of the lamp. 
表 1 各領域の材料特性

Table 1 Material constants of each area.

\begin{tabular}{ccc}
\hline Area & Relative permeability $\mu r$ & Resistivity $\rho[\Omega \mathrm{m}]$ \\
\hline Ferrite core & 1700 & 11 \\
Current source & 1 & $1.6 \times 10^{-4}$ \\
Plasma & 1 & (calculated) \\
Vacuum & 1 & 0 \\
\hline
\end{tabular}

\section{2 収束条件}

解析は図 4 に示したように, 初期電子密度を与えループを繰り返 し最終的に電子密度が収束したときに定常解が得られたと夕なし ている. 収束条件を求めるため, ループ $j$ 回目で得た電子密度を $n_{e j}$, ひとつ前のループである $j-1$ 回目で得た電子密度を $n_{e(j-1)}$ とし て変動率 $M$ を次式で定義した.

$M=\frac{n_{e(j-1)}-n_{e j}}{n_{e j}} \times 100[\%]$

図 10 はループごとに電子密度の值を解析して変動率 $M$ を導出した 一例を示したものである. 初期電子密度やイオン移動度の值で収束 するループ回数は変化するものの, いずれの場合もある值に電子密 度が収束するため, ループ回数を重ねるとやがて $M$ が 0 に収束す る. 本解析では $M \leqq 10^{-2} \%$ 収束判定条件とした。

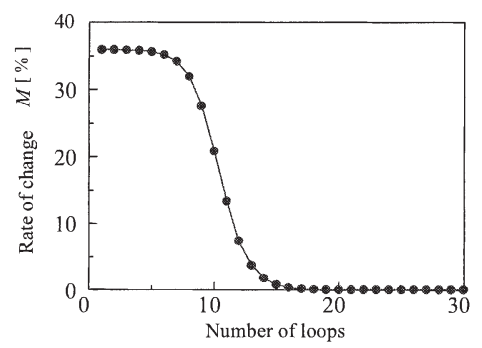

図 10 解析ループ回数と変動率 $M$

Fig.10 Rate of change $M$ with number of loops.

\section{3 解析結果と検証}

収束後のプラズマ部における各特性の分布を図 11〜図 13 に示 す. 図 11 は磁束分布で, フェライトコアの構造が開磁路であるた め磁束は空間に広く分布しているが, 磁束密度は電流源の近傍の内 壁面で最も高くなっていることがわかる，プラズマ中のうず電流お よび電界強度（図 12）も同様の位置で大きくなっている. また, 図 13 の電子温度分布之電子密度分布において, 電子温度は電流源の近 傍で最大值 $1.4 \mathrm{eV}$ を示し径方向に向かって低くなっており, 電子密 度は径方向に電流源中央の内壁から $18 \mathrm{~mm}$ 離れた位置で最大值 1.5 $\times 10^{18} \mathrm{~m}^{-3}$ の值を示している.

本解析結果を検証するために, ダブルプローブを装着したランプ を実際に試作し点灯状態におけるランプ径方向の電子温度と電子 密度の計測を行った ${ }^{10)}$. 図 14 は, 電子密度が最大となる $z$ 軸上の 位置でキャビティ管壁から外管バルブ方への距離をパラメータ $r$ として電子温度の解析值と実測值を示したもので, 距離 $r$ が $18 \mathrm{~mm}$ において解析值 $1.3 \mathrm{eV}$ に対し実測值は $1.7 \mathrm{eV}$ で少し高い值である. しかし, キャビティから外管バルブ方向に向かって減衰する傾向は

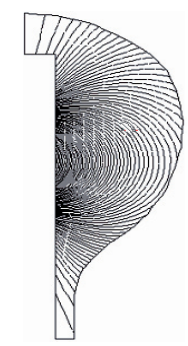

(a) Magnetic flux line

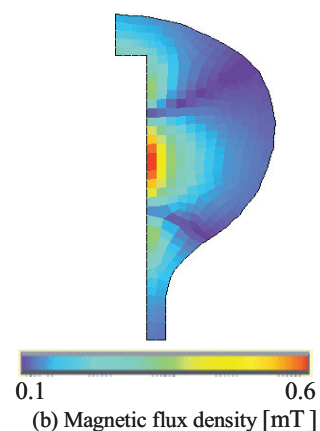

(b) Magnetic flux density [mT ]

図 11 磁束線および磁束密度分布

Fig.11 Magnetic flux line and distribution of magnetic flux density.
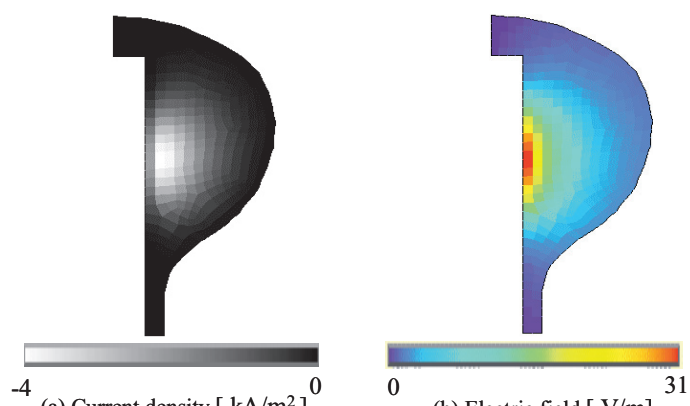

(b) Electric field [ V/m]

図 12 電流密度分布之電界強度分布

Fig.12 Distributions of current density and electric field.

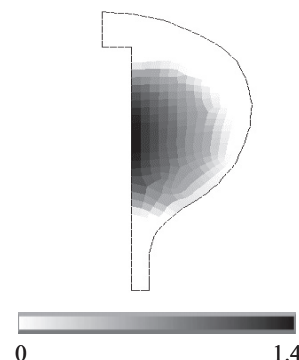

(a) Electron temperature $[\mathrm{eV}]$

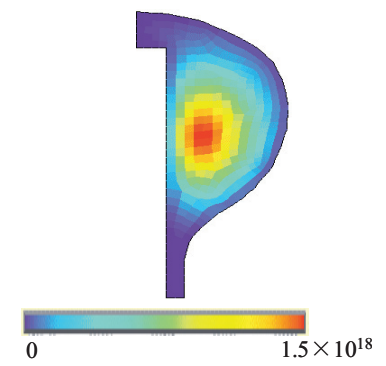

(b) Electron density $\left[/ \mathrm{m}^{3}\right]$

\section{図 13 電子温度分布之電子密度分布 \\ Fig.13 Distributions of electron temperature and electron density.}

合致していることがわかった.

図 15 は同条件における電子密度の值であり径方向の距離 $r$ が $18 \mathrm{~mm}$ のときに最大值をとり $r$ が増加するにつれて減少している ことがわかる.また $r$ がゼ口近傍および $60 \mathrm{~mm}$ 以上で急速に電子 密度が減衰するのは, 解析条件においてバルブ壁面で再結合が起 こり電子密度をゼロと設定しているためと考えられる，r=18mm において電子密度の実測值は約 $2 \times 10^{18} \mathrm{~m}^{-3}$ と解析值よりも少し高 いものの良い近似を示しており，rが $18 \mathrm{~mm}$ から増加するにつれ て実測值が隇少する傾向も解析結果と良く一致することがわか った. 


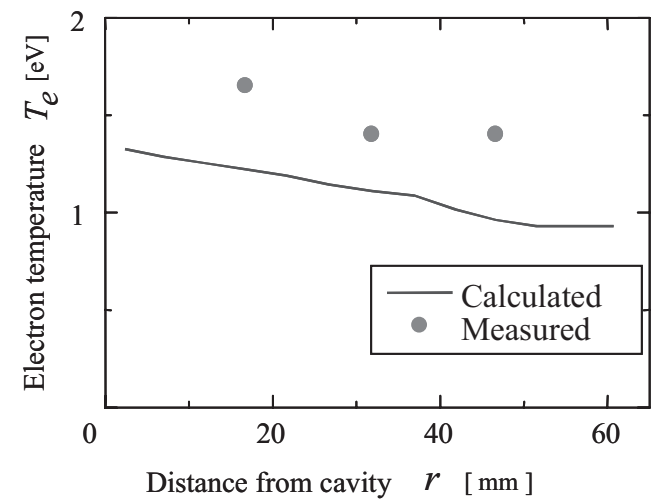

図 14 電子温度 $T_{e}$ の解析値と実測值の比較

Fig.14 Comparison of the calculated $T_{e}$ with the measured $T_{e}$.

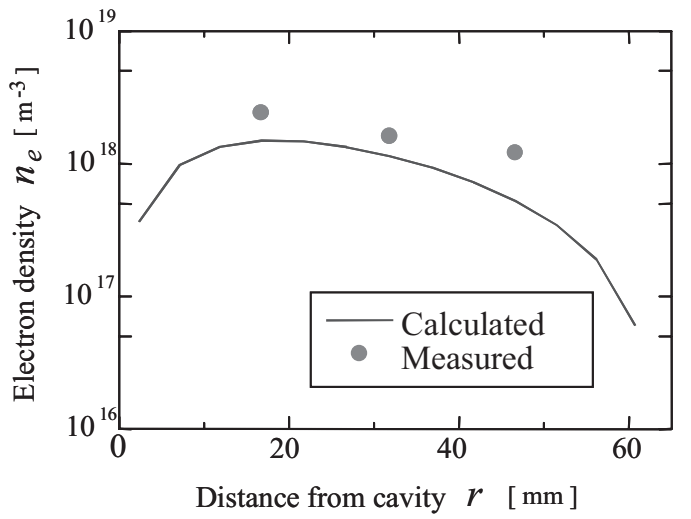

図 15 電子密度 $\boldsymbol{n}_{e}$ の解析値と実測値の比較

Fig.15 Comparison of the calculated $\boldsymbol{n}_{e}$ with the measured $\boldsymbol{n}_{e}$.

\section{5. まとめ}

球状無電柾ランプの電子密度を把握するために有限要素法を応 用した磁気とプラズマの連成解析を行った.

（1）初期電子密度を仮定して磁場解析とプラズマ解析により電子 密度を求め得られた電子密度を入力とするループ解析を導入 したところ，電子密度を一定值に収束させることができた．

(2) 解析結果である分布図から電流源近傍のプラズマ部において 磁束密度，うず電流，電界ともに最大となっていることが確認 できた．電子密度は電流源中央の内壁から外管方向へ $18 \mathrm{~mm}$ 離 れた位置で椒大值 $1.5 \times 10^{18} \mathrm{~m}^{-3}$ をとることがわかった

（3）電子密度の解析結果は実測結果を值, 傾向ともに良く近似して いた.

球状無電極ランプの電子温度および電子密度は中心に位置する誘 導コイルの近傍で最大となる.プラズマの分布状態に関しバルブの ディメンジョンや誘導コイルの諸元の影響について今後検討して いく予定である.

最後に解析に協力をいただいた長崎大学工学部卒業生 佐藤晃 平氏，米丸あゆみ氏および古閑彰氏に謝意を表する.
付 録

各記号の意味と值を以下に示す.

\begin{tabular}{|c|c|c|c|}
\hline$e$ & :電気素量 & $1.6 \times 10^{-19}$ & $\mathrm{C}$ \\
\hline$\mu_{e}$ & :電子移動度 & $1.88 \times 10^{2}$ & $\mathrm{~m}^{2} / \mathrm{V} \cdot \mathrm{S}$ \\
\hline$\mu_{i}$ & :Hg イオンの移動度 & 0.407 & $\mathrm{~m}^{2} / \mathrm{V} \cdot \mathrm{S}$ \\
\hline$n_{e 0}$ & :初期電子密度 & $10^{18}$ & $\mathrm{~m}^{-3}$ \\
\hline$p$ & : 点灯中の Ar ガスの圧力值 & 0.176 & Torr \\
\hline$P$ & : 点灯中の $\mathrm{Hg}$ ガスの压力值 & $7 \times 10^{-3}$ & Torr \\
\hline$V_{I}$ & : Hg ガスの電離電圧 & 10.42 & $\mathrm{eV}$ \\
\hline$C_{i}$ & : Hg ガスの物理定数 & $4.93 \times 10^{2}$ & $\mathrm{~m}^{2} / \mathrm{J}$ \\
\hline$k$ & :ボルツマン定数 & $1.38 \times 10^{-23}$ & $\mathrm{~J} / \mathrm{K}$ \\
\hline$m_{e}$ & :電子質量 & $9.12 \times 10^{-28}$ & $\mathrm{~g}$ \\
\hline$c$ & :Ar ガスの物理定数 & $5.3 \times 10^{-2}$ & $\mathrm{~m}^{-1} \cdot$ Torr $^{-1}$ \\
\hline$R_{A}$ & :アボガドロ定数 & $6.02 \times 10^{23}$ & $\mathrm{~mol}^{-1}$ \\
\hline$R$ & :気体定数 & 8.3145 & $\mathrm{~J} / \mathrm{mol} \cdot \mathrm{K}$ \\
\hline$T$ & : 点灯中の温度 & 373 & $\mathrm{~K}$ \\
\hline$J_{0 \theta}$ & : コイル部電流密度 & 2.3 & $\mathrm{MA} / \mathrm{m}^{2}$ \\
\hline
\end{tabular}

\section{参考文献}

（1）城戸, 平松, 小笠原, 山本 : 高効率低周波無電極ランプエバー ライト, 松下電工技報, vol. 53, No. 1, pp. 10-15 (2005) .

(2) 平松, 岡田 : 2 万 $1 \mathrm{~m}$ 無電極蛍光ランプの開発, 照学全大, p. $73(2006)$.

（3）都築, 酒井, 松尾 : 低周波低出力無電極蛍光ランプの開発, 照 学全大, p. 66 (2007).

(4) Y. Watanabe, M. Yasuda : Plasma conductivity estimation in inductively coupled electrodeless discharge by equivalent circuit, Jpn. J. Appl. Phys., vol. 37, pp. 4568-4571 (1998).

(5) 高橋則雄 : 三次元有限要素法, 電気学会, pp. 8-10 (2006).

(6) 植月, 松原, 箕田 : 高電圧工学, コロナ社, p. 21 (2006).

(7) Yuri P. Raizer : Gas discharge physics, Springer, Verlag, pp. 8-9 (1981)

（8）武田進 : 気体放電の基礎, 東京電気大学出版局, pp. 89-124 (1990).

(9) 電気学会編 : 放電ハンドブック (上), p. 170 (1998).

(10) 植月, 上田, 二又, 齋見, 掛橋 : 磁気結合型無電極ランプのプラ ズマ特性に及ぼす駆動周波数の影響, 照学誌, 92-8A, pp. 464-471 (2008).

（受付日 2008 年 9 月 29 日 $/$ 採録日 2009 年 6 月 5 日）

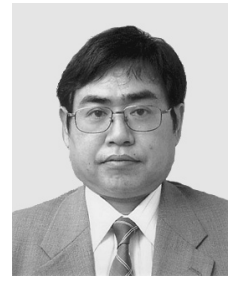

掛橋 英典（正会員）

パナソニック電工株式会社

干571-8686 大阪府門真市大字門真 1048 昭和 55 年九州大学工学部電気工学科卒業, 同年松下電工株式会社に入社. 現在パナソニッ ク電工株式会社勤務. 工学博士. 技術士 (電気. 電子部門)。照明学会・電気学会会員. 
パナソニック電工株式会社

干571-8686 大阪府門真市大字門真 1048

平成 12 年新潟大学工学部電気電子工学科卒業.

平成 14 年同大学院自然科学研究科博士前期課程

修了. 平成 17 年同大学院博士後期課程修了. 同 年松下電工株式会社に入社. 現在パナソニック電工株式会社勤務.

工学博士. 照明学会会員.

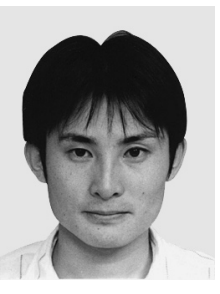

柳井 武志 (非会員)

長崎大学工学部

干852-8521 長崎市文教町 1-14

平成 12 年長崎大学工学部電気情報工学科卒業.

平成 14 年 同大学院博士前期課程電気情報工学専 攻修了. 平成 17 年 同大学院博士後期課程物質科 学専攻修了. 同年 同大学工学部電気電子工学科助手. 平成 19 年 同 大学工学部電気電子工学科助教. 工学博士. 電気学会. 日本磁気学 会会員.

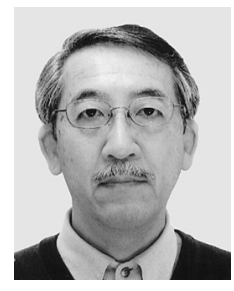

福永 博俊（正会員）

長崎大学工学部

于852-8521 長崎市文教町 1-14

昭和 50 年 九州大学工学部電気工学科卒業. 同大 学院工学研究科修士課程・博士課程を経て昭和 55 年より九州大学工学部助手. 昭和 59 年 長崎大 学助教授, 同教授, 同理事・副学長を経て平成 20 年より同工学部 電気電子工学科教授. 工学博士. 日本磁気学会副会長. 電気学会九 州支部長. 応用物理学会・日本金属学会 - 照明学会 - IEEE 会員.

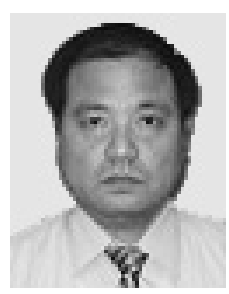

植月 唯夫 (専門会員)

津山工業高等専門学校電気電子工学科

干708-8509 岡山県津山市沼 624-1

昭和 54 年静岡大学電気工学科卒業. 昭和 57 年同 大学院修士課程修了後, 松下電工株式会社に勤務 し, 照明用光源の研究開発に従事. 平成 14 年 4

月津山工業高等専門学校電気電子工学科に教授として赴任. 現在に 至る. 工学博士. 照明学会・電気学会・プラズマエレクトロニクス 分科会会員. 